\title{
Off Their Trolley -- Understanding Online Grocery Shopping Behaviour
}

\author{
Lillian Clark ${ }^{\prime}$ and Peter Wright ${ }^{2}$ \\ 1 Department of Computer Science, University of York, UK \\ 2 Art \& Design Research Centre, Sheffield Hallam Unjversity, UK
}

\begin{abstract}
The artefact or object-based models commonly used in interaction design for describing users are inadequate for understanding the complexity and variability of online consumer behaviour, while traditional models of consumer behaviour do not reflect the user's ability to shape their shopping experience online. To address this gap a framework has been developed for modelling online consumer behaviour and in this paper this framework is used to develop a survey of online grocery shopping in the UK. Analysis of the survey reveals several issues of concern, particularly dissatisfaction with product search capabilities and a conflict between the online consumer's desires for both empowerment and experimentation.
\end{abstract}

\section{Introduction}

It is axiomatic that interaction design begins with a thorough understanding of the user, and this understanding is often developed and communicated through conceptual models of the user that are grounded in specific activities or artefacts [4$6,13]$. The task of user modelling becomes particularly difficult in the context of online shopping systems. Consumer behaviour itself, regardless of venue, is highly complex in nature $[14,15]$, varies greatly for different demographic groups and can vary even for the same consumer depending on context [12]. This level of complexity and variability cannot be adequately reflected in models that are grounded to a particular task or artefact, and reliance on single-aspect models leads to neglect of the whole sphere of online consumer behaviour [1,20]. Adding to these difficulties is the fact that online consumers differ from "terrestrial" ones in that they are also able to initiate and shape their shopping experiences through the use of interactive shopping systems $[7,9,17]$. Consequently, traditional models of consumer behaviour are also insufficient for modelling online consumer behaviour as these traditional models rely on the premise of a primarily passive and reactive consumer $[10,11,18]$. 
Therefore in order to develop the understanding of online consumer behaviour needed for effective interaction design, we need a way of modelling users that facilitates identification and exploration of the various aspects relevant to online consumer behaviour.

To address this need, we have developed a framework for modelling online consumer behaviour and demonstrated its use in developing design personas, identifying behavioural patterns, and illuminating potential interaction problems. In this paper we will examine how this framework can be used to further explore the diversity of online consumer behaviour by developing and administering a framework-based survey designed to examine the behaviour of online grocery shoppers in the UK.

\section{The e-Consumer Framework}

In Clark \& Wright [2] we presented the e-Consumer Framework (e-CF) as a structure for conceptual modelling of online consumer behaviour. The e-CF, which was derived from existing literature and research into both online and general consumer behaviour, is based on seven parameters of online consumer behavioural (Fig. 1).

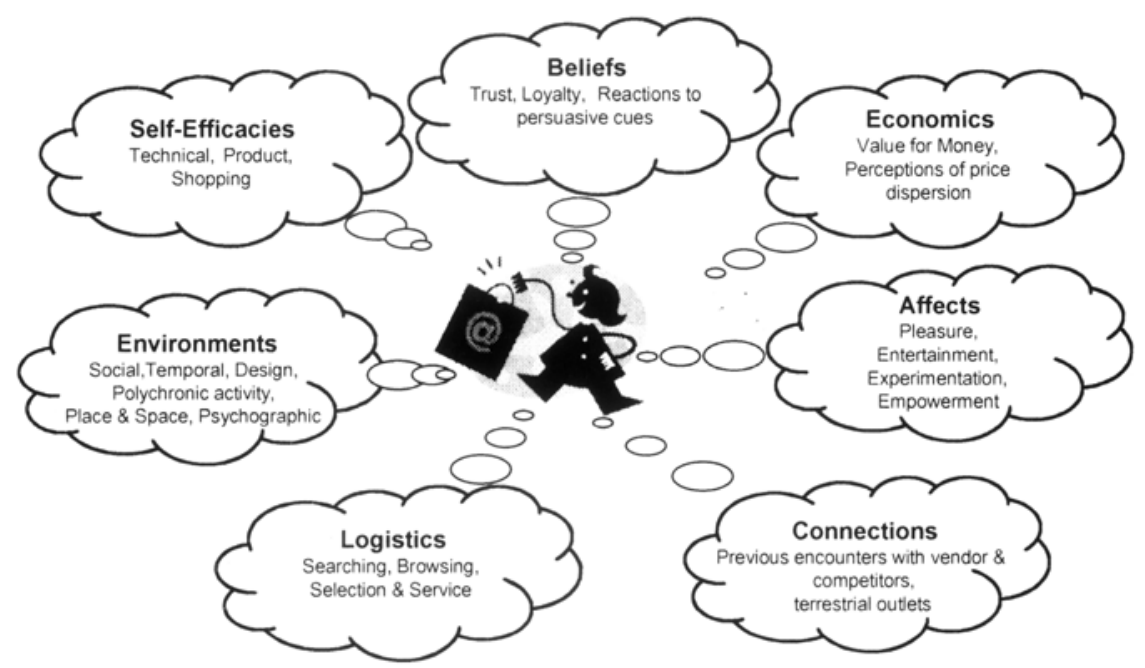

Fig. 1. The e-Consumer Framework (e-CF)

This multi-dimensional framework provides a comprehensive yet practical platform for conceptual modelling of online consumer behaviour, facilitating identification, description and prioritisation of relevant behavioural aspects while recognising the complexity and variety of online consumer behaviour. To date, we have demonstrated how the e-CF provides a structure for collecting and processing 
qualitative data and subsequent design persona development. In addition, e-CF based summaries of qualitative data can be used to develop insight into usage patterns and identify potential interaction issues both within and across domains.

\section{Rationale For An e-CF Based Survey}

In our previous study we examined online grocery shopping behaviour by observation and interview of eight participants who identified themselves as regular users of online supermarkets. In addition to demonstrating how personas could be built from individual e-CF based descriptions of each participant, we also aggregated the results for all online grocery participants into an e-CF based summary which enabled identification of various behaviour patterns common to most or all of the participants and uncovered some potential issues of concern to interaction designers including conflicts between the participants' desire for empowerment and their desire for experimentation, a lack of loyalty to terrestrial outlets of the online supermarket, a degree of difficulty in finding certain items, an avoidance of polychronic activity and a seeming indifference to site design.

The e-CF based ethnographic study illuminated the complexity of the online grocery shopper's behaviour, particularly the variety of aspects that influence such behaviour. By developing an e-CF based survey of online grocery shopping, we can use quantitative data to explore the diversity of online grocery shopping behaviours and identify common features and issues relevant to interaction design.

\section{The Survey}

To construct the survey, we developed over 60 closed questions each designed to cover one or more e-CF themes. Questions were designed to measure either perceived behaviour or attitudes, with themes duplicated with alternative wording where possible to minimise response bias [3]. The first question asked of all respondents was as follows:

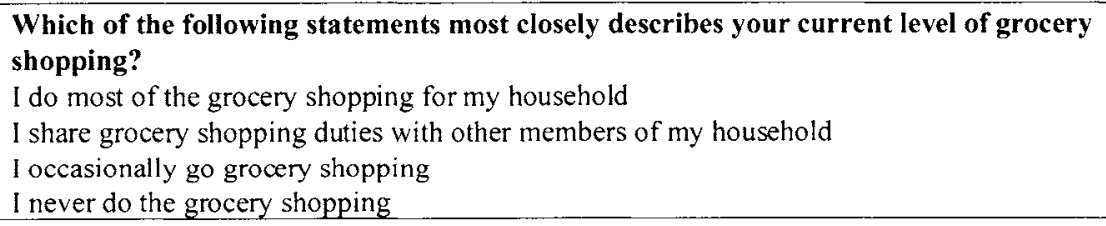

In addition to exploring the themes of Self-Efficacy and Environments, this question acted as a primary filter, as those respondents who indicated that they never did the grocery shopping could then be immediately eliminated from the rest of the survey.

Respondents were then asked several questions concerning gender, age, occupation and household size so that demographic profiles could be built. The next 
set of questions was intended to explore various e-CF themes in general online shopping behaviour and non-Internet (terrestrial) food shopping.

\begin{tabular}{|l|l|}
\hline e-CF Themes & Behavioural Questions asked of all respondents \\
\hline $\begin{array}{l}\text { Logistics } \\
\text { Environments }\end{array}$ & $\begin{array}{l}\text { Are there particular religious, ethical or health considerations that affect } \\
\text { your grocery shopping? (Y/N) }\end{array}$ \\
\hline Connections & Where do you do most of your non-Internet food shopping? \\
\hline Connections & $\begin{array}{l}\text { On average, how often do you buy your groceries from a supermarket, } \\
\text { grocer or any place other than the Internet? }\end{array}$ \\
\hline Self-Efficacies & $\begin{array}{l}\text { Aside from groceries, have you ever bought any of the following types of } \\
\text { products online?: Books, Music/Films, Travel, Electronics, House/Garden, } \\
\text { Clothing, Toys/Gifts, Computer Hardware/Software, I have never bought } \\
\text { anything online }\end{array}$ \\
\hline
\end{tabular}

The next set of questions was intended to explore the extent of various behaviours manifested in food shopping and terrestrial food shopping in particular. For these questions, a 5-point Likert scale was used for responses.

\begin{tabular}{|c|c|}
\hline e-CF Themes & $\begin{array}{l}\text { Questions on general Food Shopping Behaviours } \\
\text { (Never, Rarely, Sometimes, Frequently, Almost Always) }\end{array}$ \\
\hline Beliefs & $\begin{array}{l}\text { Do you store your credit/debit card details at your favourite online } \\
\text { shopping sites? }\end{array}$ \\
\hline Self-Efficacies & Do you every find online shopping confusing? \\
\hline Self-Efficacies & How often do you cook means from scratch? \\
\hline $\begin{array}{l}\text { Affects } \\
\text { Logistics }\end{array}$ & Do you tend to buy the same brands or types of groceries over and over? \\
\hline Economics & $\begin{array}{l}\text { How often do you compare prices before deciding where to buy your } \\
\text { groceries? }\end{array}$ \\
\hline Logistics & How often do you study the label on a new item before purchasing? \\
\hline
\end{tabular}

The next set of questions was intended to measure attitudes towards food and food shopping in general, using a 5-point Likert scale.

\begin{tabular}{|l|l|}
\hline e-CF Themes & $\begin{array}{l}\text { Questions on Attitudes } \\
\text { (Strongly Disagree, Disagree, Neutral, Agree, Strongly Agree) }\end{array}$ \\
\hline Self-Efficacies & I am comfortable using my computer to access the Internet \\
\hline Self-Efficacies & $\begin{array}{l}\text { I like to try new things out on the computer myself, rather than ask } \\
\text { someone to help me }\end{array}$ \\
\hline Environments & Being able to grocery shop at any time of day is important to me \\
\hline Environments & Buying organic or Fair Trade products is important to me \\
\hline Affects & Food shopping is boring \\
\hline Affects & I enjoy cooking for my family and friends \\
\hline Environments & Grocery shopping is easier to do if I'm on my own \\
\hline Affects & I don't like someone else picking out my groceries for me \\
\hline Affects & I enjoy food shopping \\
\hline Affects & I like to try different places to buy my groceries \\
\hline
\end{tabular}

Through a filtering question, respondents were then split into two groups -- those who currently did any part of their grocery shopping online (OGS) and those who 
did not currently do so. The OGS were then asked questions about their online grocery shopping behaviours and attitudes as follows:

\begin{tabular}{|l|l|}
\hline e-CF Themes & Questions on Behaviour when shopping for groceries online \\
\hline $\begin{array}{l}\text { Beliefs } \\
\text { Connections }\end{array}$ & Where do you do most of your online grocery shopping? \\
\hline Connections & $\begin{array}{l}\text { Overall, where do you buy most of your groceries? } \\
\text { (Online, From a Supermarket, From a Grocer or other local shop, Other) }\end{array}$ \\
\hline Environments & On average, how often do you buy your groceries online? \\
\hline
\end{tabular}

\begin{tabular}{|l|l|}
\hline e-CF Themes & $\begin{array}{l}\text { Questions on Behaviour when shopping for groceries online } \\
\text { (Never, Rarely, Sometimes, Frequently, Almost Always) }\end{array}$ \\
\hline $\begin{array}{l}\text { Beliefs } \\
\text { Connections }\end{array}$ & $\begin{array}{l}\text { If you need to go to a supermarket, do you go to the same vendor that } \\
\text { provides your online grocery shopping? }\end{array}$ \\
\hline $\begin{array}{l}\text { Beliefs } \\
\text { Environments }\end{array}$ & How often do you check out Special offers or items on sale? \\
\hline Environments & $\begin{array}{l}\text { How often do you do your online grocery shopping from your home } \\
\text { computer? }\end{array}$ \\
\hline $\begin{array}{l}\text { Economics } \\
\text { Logistics }\end{array}$ & $\begin{array}{l}\text { How often do you time your online grocery shopping to take advantage of } \\
\text { cheaper delivery charges? }\end{array}$ \\
\hline $\begin{array}{l}\text { Logistics } \\
\text { Environments }\end{array}$ & How often do you use the Search box to find an item? \\
\hline $\begin{array}{l}\text { Logistics } \\
\text { Environments }\end{array}$ & How often do you scan or browse categories to find an item? \\
\hline Logistics & How often do you use the "Notes" or "Instructions" feature? \\
\hline Logistics & How often do you use the "My Favourites" or "Last Order" feature? \\
\hline Logistics & How often do you have problems finding items? \\
\hline $\begin{array}{l}\text { Affects } \\
\text { Logistics }\end{array}$ & How often do you try new products or brands? \\
\hline $\begin{array}{l}\text { Beliefs Affects } \\
\text { Logistics }\end{array}$ & How often do you buy something on impulse? \\
\hline Environment & How often do you do your online grocery shopping alone? \\
\hline
\end{tabular}

\begin{tabular}{|l|l|}
\hline e-CF Themes & $\begin{array}{l}\text { Questions on Respondent Attitudes } \\
\text { (Strongly Disagree, Disagree, Neutral, Agree, Strongly Agree) }\end{array}$ \\
\hline Economics & Buying Groceries online saves me money \\
\hline I don't like being interrupted when grocery shopping online \\
\hline Affects & 1 feel more in control of my grocery shopping when I do it online \\
\hline Environments & I don't mind talking to people while doing my online grocery shopping \\
\hline $\begin{array}{l}\text { Connections } \\
\text { Logistics }\end{array}$ & Buy groceries online hasn't affected the types of things I buy \\
\hline Environments & My favourite online grocery site is easy to use \\
\hline $\begin{array}{l}\text { Affects } \\
\text { Connections }\end{array}$ & $\begin{array}{l}\text { I'm more likely to buy something new if I see it in a supermarket or shop } \\
\text { than online }\end{array}$ \\
\hline $\begin{array}{l}\text { Economics } \\
\text { Connections }\end{array}$ & $\begin{array}{l}\text { The best thing about buying groceries online is that I spend less money } \\
\text { than I would in a supermarket }\end{array}$ \\
\hline Affects & I miss being able to pick out my own produce when shopping online \\
\hline $\begin{array}{l}\text { Affects } \\
\text { Connections }\end{array}$ & $\begin{array}{l}\text { If I had the time, I would prefer to buy my groceries in person rather than } \\
\text { online }\end{array}$ \\
\hline
\end{tabular}




\begin{tabular}{|l|l|}
\hline e-CF Themes & $\begin{array}{l}\text { Questions on Respondent Attitudes } \\
\text { (Strongly Disagree, Disagree, Neutral, Agree, Strongly Agree) }\end{array}$ \\
\hline Environments & $\begin{array}{l}\text { I prefer not to be distracted when online grocery shopping, as I need to } \\
\text { concentrate on what I'm doing }\end{array}$ \\
\hline
\end{tabular}

\begin{tabular}{|l|l|}
\hline e-CF Themes & $\begin{array}{l}\text { Thinking about the last time you bought groceries online, please rate } \\
\text { the vendor on... } \\
\text { (Excellent, Good, Acceptable, Below Average, Poor) }\end{array}$ \\
\hline Environments & Ease of use \\
\hline Logistics & Quality of Products \\
\hline Logistics & Product Selection \\
\hline Logistics & Quality of Service \\
\hline Environments & Web Site appearance \\
\hline Economics & Price \\
\hline
\end{tabular}

\begin{tabular}{|l|l|}
\hline e-CF Themes & Thinking about the last time you bought groceries online... \\
\hline Beliefs & Do you store your credit/debit card details on that site? \\
\hline Beliefs & Do you store your login details for that site? \\
\hline Environments & $\begin{array}{l}\text { Do you have the web address of the site stored in Bookmarks or } \\
\text { Favourites? }\end{array}$ \\
\hline
\end{tabular}

While the intent of this phase of the survey was not to build a specific e-CF based profile of those who did not currently do any part of their household grocery shopping online (NOGS), several questions were developed for this group in case more comparable information was required.

\begin{tabular}{|c|c|}
\hline e-CF Themes & $\begin{array}{l}\text { Questions on frequency of Respondent Behaviour when shopping for } \\
\text { groceries online } \\
\text { (Never, Rarely, Sometimes, Frequently, Almost Always) }\end{array}$ \\
\hline Beliefs & How often do you use credit or debit cards to pay for your food shopping? \\
\hline Beliefs & How often do you check out Special offers or items on sale? \\
\hline Logistics & How often do you use the supermarket nearest your home? \\
\hline Environments & Do you try to do your grocery shopping at a particular time of day? \\
\hline Environments & Do you try to do your grocery shopping on a particular day of the week? \\
\hline \multicolumn{2}{|l|}{ e-CF Theme } \\
\hline Connections & Have you ever tried to buy your groceries online? \\
\hline
\end{tabular}

\section{Administering The Survey}

The survey was built and administered online using the QuestionPro platform (www.questionpro.com) and ran from February to April 2006. Respondents were solicited from within the UK, and the opportunity to win a $£ 50$ gift certificate was offered in order to encourage participation and valid responses, as respondents needed to identify themselves to be eligible for the prize draw. The results from the survey are detailed in Appendix A. 


\section{Implications For Interaction Design}

In conducting this survey, our goal was to explore the diversity of online grocery shopping behaviours and identify common features and issues relevant to interaction design. To achieve this goal we transformed the survey results shown in Appendix A into an overall profile of the 46 respondents who identified themselves as OGS follows.

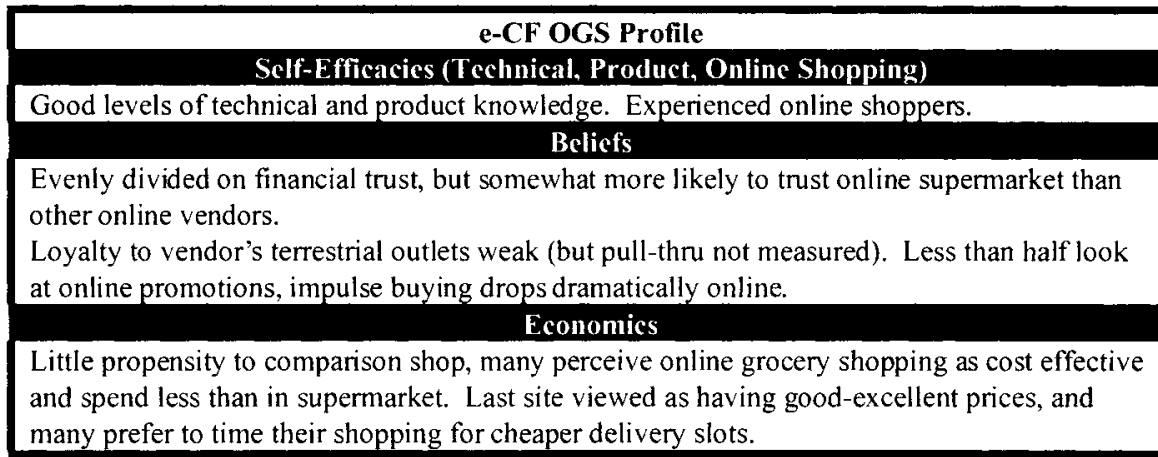

\section{Affect}

See online grocery shopping as gaining control over time, but losing control over selection, and most would prefer to shop in person if they had the time despite rating both online vendor's product selection and quality as good or better. Food shopping (regardless of venue) and cooking viewed as pleasurable activities. While there is a marked tendency to repeatedly buy the same products/brands regardless of venue, the inclination to experiment with product purchases decreases when online, with only a weak correlation between online and terrestrial behaviours. Experimentation with vendors was rated slightly higher

\section{Connections}

Slightly less than half the grocery shopping done online, as most continue to terrestrial shop on a regular basis (bi-weekly or more). The terrestrial environment strongly seen as the platform for product experimentation. Online shopping not perceived as having much impact on the types of products bought, slightly less than half use the same grocer for online and terrestrial and a third like to vary their vendor.

\section{Logistics}

Tendency to make a shopping list decreases somewhat online, My Favourites/Last Order is the strong preference for driving selection process. Browsing slightly preferred to Searching, no correlation between selection methodology and likelihood of encountering problems, but most report encountering at least some problems finding items. Despite concerns about controlling selection, very few use the Notes or Instructions features. More likely to store login/registration details with vendor than card details.

\section{Environments}

Mostly shop from home, once a month or less. Variable attitudes towards distractions, but half prefer not to be interrupted. Grocery shopping viewed as being easier to do alone, and more likely to online shop alone. Half saw Fair Trade/Organic as important, a third had religious, ethical or health considerations that affected their food shopping. Most perceived their online grocer's site as easy to use and rated site appearance highly. 
From this profile we can identify and explore a number of issues relevant to interaction design.

Self-Efficacies: There was little diversity in the levels of Self-Efficacy (skills, knowledge and confidence) amongst the OGS, a result that would encourage the development of online supermarket interactions based on a relatively high level of experience and expertise in online shopping, grocery purchasing and Internet usage. However these results may present a biased picture as those less familiar with the Internet are less likely to respond to an online survey in the first place. In fact, our previous ethnographic study of online grocery shopping behaviour uncovered a greater level of diversity in the levels of technical self-efficacy than in this survey, suggesting that design based on high levels of technical expertise can present barriers to both existing and new users who are less skilled in these areas.

Loyalty: Respondents often used different vendors for online and terrestrial shopping, an issue that would at first glance not seem relevant to interaction design. However, given the continued frequency of terrestrial shopping amongst the respondents and the fact that the major online shopping sites in the UK are run by the supermarket chains, this lack of loyalty would naturally concern vendors who would in turn develop marketing activities taken to encourage vendor loyalty. Such activities will naturally need to be reflected in interaction design considerations, such as promotion of loyalty card schemes.

Searching and Browsing: Category browsing was more popular with respondents than use of the search facility. While there was no correlation between product location strategy and frequency of online shopping, there was a reasonably strong correlation between use of the search facility and the Notes/Instructions feature. This could suggest that use of the Search facility is more common for those shoppers particularly concerned about controlling product selection. It should also be noted that there was little correlation between browsing or searching activity, or between either activity and the likelihood of encountering problems in locating items. However, over half the respondents reported that they sometimes encountered problems finding items, and $15.6 \%$ said these problems were frequent. These results imply that regardless of product selection method used, finding items may be an issue for many online grocery shoppers and interaction designers need to consider how to improve search and scan facilities.

Empowerment: Respondents clearly had concerns about the level of control they had over their grocery shopping. On one hand, $73.9 \%$ agreed that being able to shop at any time of day was important, over $40 \%$ saw online grocery shopping as more cost-effective than terrestrial and levels of reported impulse purchasing dropped substantially online. However, the vast majority of respondents agreed they missed the experience of picking their own produce, half did not like having their grocery items picked out by other people, and over half said they would prefer to do their grocery shopping in person if time allowed. Unsurprisingly, less than a quarter of the respondents agreed with the statement that online grocery shopping gave them increased control. It is clear that the current methods of product selection in online supermarkets are working against the online consumer's need to feel in control of their shopping experience.

Experimentation: While levels of reported new product purchasing activity decreased only slightly online, the number of those claiming they never or rarely did so rose substantially and over three-quarters of the respondents agreed they were 
more likely to try new products in a supermarket than online. These results suggest that customers feel their ability to experiment is constrained when shopping online.

Polychronic Activity: While the survey did not specifically ask what other activities respondents engaged in while online grocery shopping, $52.2 \%$ of the respondents said they did not like being interrupted when online grocery shopping, and $31 \%$ said they preferred not to be distracted as they needed to concentrate when online grocery shopping. $30.3 \%$ said they minded talking to others while shopping. These results support our earlier observations that online grocery shoppers do indeed view their activities as requiring a degree of concentration, with some degree of tolerance for interruption.

Site Usability and Appearance: A large majority of the respondents gave positive ratings to the appearance and particularly the ease of use of their favourite online grocery site. The site features "My Favourites" and "Last Order" were particularly popular with respondents. Product search tools and Special Offers features were less popular while use of the "Notes" and "Instructions" feature was very limited, despite respondent concerns about controlling their product selection. This would seem to indicate that online grocery shoppers do not have any particular concerns about site design or usability, but are not making full use of site features, even those that could address their product selection issues.

\section{Conclusions and Suggestions for further research}

Online grocery shopping in the UK has been particularly successful to date $[8,19]$, however it is clear there is still considerable room for improving the user's experience, especially their perception of control over their grocery shopping. Consideration needs to be given to helping online shoppers locate products through more intelligent search functionality and/or more intuitive taxonomies (a search for "rice pudding" should not produce the same results as "pudding rice") and barriers to use of site features that enhance control (such as the ability to provide specific product instructions to the vendor) needs to be examined. Addressing the online grocery shopper's need to experiment is a more difficult challenge, especially as presenting the user with extra information or displays is quite likely to conflict with their desire to control their shopping experience. One possible way to address both the user's desire to experiment and to control their grocery shopping experience is through Virtual Reality interfaces that can enhance product perception through telepresence [16].

Administering any type of consumer survey online needs to be carefully considered. Schiffman and Kanuk [14] point out that the anonymity of the Internetbased survey provides an environment where respondents can on one hand be more forthcoming in their responses but on the other hand also invent fictional profiles. To these concerns we should also add the self-selecting nature of an online survey in that it will naturally attract respondents who are comfortable with the Internet and have a reasonable level of engagement with the topic in question. Consideration should therefore be given to administering future iterations of this survey terrestrially as well as on the Internet, ideally with the cooperation of one or more UK supermarkets. 
Several intriguing trends and correlations appeared in the survey results that were outside the scope of this particular study but certainly warrant further investigation. For instance, an e-CF model of those respondents who did not currently buy groceries online (the so-called NOGS) could be developed. Such a model, especially if compared to online grocery shopper models, could provide additional insights into those factors that inhibit or encourage online shopping behaviours.

\section{REFERENCES}

1. L. Clark and P. Wright, A Review of Common Approaches to Understanding Online Consumer Behaviour, in Proceedings of the IADIS International Conference e-Society 20105, Qawra, Malta, pp. 211-218.

2. L. Clark and P. Wright, e-CF: A Framework for Understanding Online Consumer Behaviour, 2007. (Awaiting publication).

3. D. Clark-Carter, Quantitative Psychological Research (Psychology Press, Hove, 2004).

4. A. Cooper, The Inmates Are Running The Asylum (SAMS Publishing, Indianapolis, 1999).

5. A. Cooper and R. Reimann, About Face 2.0): The Essentials of Interaction Design. (Wiley Publishing, Indianapolis, 2003).

6. A. Dix, J. Finlay, G.D. Abowd, and R. Beale, Human-Computer Interaction (Pearson Education Limited, Harlow, 2004).

7. A.F. Firat and A. Venkatesh, Liberatory Postmodernism and the Reenchantment of Consumption, Journal of Consumer Research 22 pp. 239-267 (1995).

8. IMRG, (August I, 2005), Tesco has announced bumper half year results; http:/www.imrg.org/802569750045BDAD/(search)/78440CC46A72170B80256F25004l 1D6C? Opendocument\&highlight $=2$.

9. J. McCarthy and P. Wright, Technology as Experience (The MIT Press, Cambridge, 2004).

10. J.U. McNeal, An Introduction to Consumer Behavior (Wiley, New York, 1973).

11. R. Markin Jr., Consumer Behaviour. A Cognitive Orientation (New York, Wiley, New York, 1974).

12. D. Miller, P. Jackson, N. Thrift, B. Holbrook, and M. Rowlands, Shopping, place and identity (Routledge, Padstow, 1998).

13. J. Preece, Y. Rogers, and H. Sharp, Interaction Design (John Wiley \& Sons, New York, 2002).

14. L.G. Schiffman and L.L Kanuk, Consumer Behavior (Pearson Prentice Hall, Upper Saddle River, 2004).

15. M. Solomon, G. Bamossy, and S. Askegaard, Consumer Behaviour: A European Perspective (Pearson Education Limited, Harlow, 2002).

16. K.S. Suh and S. Chang, User interfaces and consumer perceptions of online stores: The role of telepresence, Behaviour \& Information Technology 25(2) pp. 99-113(2006).

17. I. Szmigin, Understanding the Consumer (Sage Publications Ltd, London, 2003).

18. C.G. Walters, Consumer Behavior: Theory and Practice (Richard D. Irwin Inc, Homewood, 1976).

19. N. Wingfield and E. Anthes, Selling Food Online To Get Further Boost as Amazon Joins In, The Wall Street Journal Europe, June $24^{\text {th }} 2003$, page A6.

20. M. Wolfinbarger and M.C. Gilly, eTailQ: dimensionalizing, measuring and predicting etail quality, Journal of Retailing 79, pp. 183-198 (2003). 


\section{Appendix A - Survey Results}

\begin{tabular}{|l|l|l|l|l|}
\hline \multirow{2}{*}{} & \multicolumn{3}{|c|}{ Frequency } & \multicolumn{2}{c|}{ Valid \% } \\
\cline { 2 - 5 } & OGS & NOGS & OGS & NOGS \\
\hline Gender & & & & \\
Male & 23 & 19 & 50 & 33.3 \\
Female & 23 & 38 & 50 & 66.7 \\
\hline Age: & 2 & & & \\
Under 24 & 24 & 19 & 4.3 & 5.3 \\
$25-34$ & 13 & 19 & 28.2 & 33.3 \\
$35-44$ & 6 & 15 & 13 & 33.3 \\
$45-60$ & 1 & 1 & 2.2 & 26.3 \\
$60+$ & & & & 1.8 \\
\hline Occupation: & 37 & 43 & 80.4 & 75.4 \\
Working Full-time & 4 & 11 & 8.7 & 19.3 \\
Student & 1 & 1 & 2.2 & 1.8 \\
Retired & 0 & 1 & 0 & 1.8 \\
Homemaker & 4 & 1 & 8.7 & 1.8 \\
Other & & & & \\
\hline Household Size & 8 & 12 & 17.4 & 21.1 \\
1 & 22 & 24 & 47.8 & 42.1 \\
2 & 6 & 14 & 13 & 24.6 \\
3 & 8 & 4 & 17.4 & 7.0 \\
4 & 2 & 3 & 4.3 & 4.3 \\
$5+$ & & & & \\
\hline
\end{tabular}

\begin{tabular}{|l|c|}
\hline Which of the following statements most closely describes your current level of & \\
grocery shopping? & \\
I do most of the grocery shopping for my household & 69.6 \\
I share grocery shopping duties with other members of iny household & 23.9 \\
I occasionally go grocery shopping & 6.5 \\
\hline Are there particular religious, ethical or health considerations that affect your & \\
grocery shopping? & 37 \\
Yes & 63 \\
No & \\
Where do you do most of your non-Internet food shopping? & 32.6 \\
Tesco & 15.2 \\
Sainsburys & 6.5 \\
Asda & 4.3 \\
Iceland & 8.7 \\
Morrisons & 8.7 \\
Naitrose & 2.2 \\
Other & 21.7 \\
\hline
\end{tabular}

\begin{tabular}{|l|c|}
\hline On average, how often do you buy your groceries from a supermarket, grocer or any & $\%$ of OGS \\
place other than the Internet? & \\
Less than once a month & 6.5 \\
Once a month & 10.9 \\
Once every 2 weeks & 13.0 \\
Once a week & 52.2 \\
2 or more times a week & 17.4 \\
\hline
\end{tabular}




\begin{tabular}{|l|c|}
\hline Aside from groceries, have you ever bought any of the following types of products & $\%$ of OGS \\
online? & \\
Books & \\
Music/Films & 93.5 \\
Travel & 87.0 \\
Electronics & 78.3 \\
House/Garden & 67.4 \\
Clothing & 47.8 \\
Toys/Gifts & 60.9 \\
Computer Hardware/Software & 69.5 \\
I have never bought anything online & 67.4 \\
\hline
\end{tabular}

\begin{tabular}{|l|c|}
\hline & \% of OGS \\
\hline Where do you do most of your online grocery shopping? & 69.6 \\
Tesco.com & 13.0 \\
Sainsburys To You & 2.2 \\
Asda.com & 8.7 \\
Ocado/Waitrose & 6.5 \\
Other & \\
\hline Overall, where do you buy most of your groceries? & 40.0 \\
Online & 53.3 \\
From a Supermarket & 2.2 \\
From a Grocer or other local shop & 4.4 \\
Other & \\
\hline On average, how often do you buy your groceries online? & 35.6 \\
Less than once a month & 24.4 \\
Once a month & 24.4 \\
Once every 2 weeks & 15.6 \\
Once a week & 0.0 \\
\hline 2or more times a week
\end{tabular}

\begin{tabular}{|l|c|c|c|c|c|}
\hline OGS on general shopping & $\mathbf{N} \%$ & $\mathbf{R} \%$ & $\mathbf{S \%}$ & $\mathbf{F} \%$ & $\mathbf{A} \%$ \\
\hline How often do you cook means from scratch? & 2.2 & 2.2 & 17.4 & 52.2 & 26.1 \\
\hline Do you every find online shopping confusing? & 8.7 & 50.0 & 39.1 & 0.0 & 2.2 \\
\hline $\begin{array}{l}\text { Do you store your credit/debit card details at your favourite } \\
\text { online shopping sites? }\end{array}$ & 32.6 & 8.7 & 23.9 & 2.2 & 32.6 \\
\hline
\end{tabular}

( $\mathrm{N}=$ Never, $\mathrm{R}=$ Rarely, $\mathrm{S}=$ Sometimes, $\mathrm{F}=$ Frequently, $\mathrm{A}=\mathrm{\Lambda}$ lways $)$

\begin{tabular}{|l|c|c|c|c|c|}
\hline OGS on terrestrial shopping & $\mathbf{N \%}$ & $\mathbf{R \%}$ & $\mathbf{S \%}$ & $\mathbf{F \%}$ & $\mathbf{A \%}$ \\
\hline $\begin{array}{l}\text { How often do you study the label on a new item before } \\
\text { purchasing? }\end{array}$ & 0.0 & 17.4 & 23.9 & 34.8 & 23.9 \\
\hline $\begin{array}{l}\text { How often do you compare prices before deciding where to } \\
\text { buy your groceries? }\end{array}$ & 10.9 & 41.3 & 23.9 & 15.2 & 8.7 \\
\hline $\begin{array}{l}\text { Do you tend to buy the same brands or types of groceries over } \\
\text { and over? }\end{array}$ & 0.0 & 0.0 & 15.6 & 53.3 & 31.1 \\
\hline How often do you do your grocery shopping alone? & 2.2 & 8.9 & 20.0 & 33.3 & 35.6 \\
\hline How often do you buy something on impulse? & 0.0 & 15.6 & 46.7 & 37.8 & 0.0 \\
\hline How often do you try new products or brands? & 0.0 & 11.1 & 66.7 & 20.0 & 2.2 \\
\hline How often do you make a list before shopping? & 8.9 & 17.8 & 17.8 & 28.9 & 26.7 \\
\hline
\end{tabular}

(N-Never, R-Rarely, S-Sometimes, F-=Frequently, A-Always)

\begin{tabular}{|l|c|c|c|c|c|}
\hline OGS on general shopping & SA \% & A\% & N\% & D\% & SD\% \\
\hline I like to try different places to buy my groceries & 2.2 & 28.3 & 34.8 & 30.4 & 4.3 \\
\hline I enjoy food shopping & 26.1 & 32.6 & 34.8 & 6.5 & 0.0 \\
\hline
\end{tabular}




\begin{tabular}{|l|c|c|c|c|c|}
\hline OGS on general shopping & SA\% & $\mathbf{A \%}$ & $\mathbf{N \%}$ & $\mathbf{D} \%$ & SD\% \\
\hline I don't like someone else picking out my groceries for me & 6.5 & 43.5 & 32.6 & 15.2 & 2.2 \\
\hline Grocery shopping is easier to do if I'm on my own & 39.1 & 30.4 & 19.6 & 8.7 & 2.2 \\
\hline I enjoy cooking for my family and friends & 32.6 & 45.7 & 13.0 & 4.3 & 4.3 \\
\hline Food shopping is boring & 6.5 & 19.6 & 32.6 & 30.4 & 10.9 \\
\hline Buying organic or Fair Trade products is important to me & 22.2 & 28.9 & 31.1 & 11.1 & 6.7 \\
\hline $\begin{array}{l}\text { Being able to grocery shop at any time of day is important to } \\
\text { Ine }\end{array}$ & 43.5 & 30.4 & 19.6 & 4.3 & 2.2 \\
\hline $\begin{array}{l}\text { I like to try new things out on the computer myself, rather } \\
\text { than ask someone to help me }\end{array}$ & 24.4 & 48.9 & 22.2 & 4.4 & 0.0 \\
\hline I am comfortable using my computer to access the lnternet & 89.1 & 8.7 & 0.0 & 0.0 & 2.2 \\
\hline
\end{tabular}

( $\mathrm{SA}=$ Strongly Agree, $\mathrm{A}=\mathrm{Agree}, \mathrm{N}=$ Neutral, $\mathrm{D}=$ Disagree, $\mathrm{SD}=$ Strongly Disagree)

\begin{tabular}{|l|c|c|c|c|c|}
\hline OGS on online grocery shopping habits & $\mathbf{N \%}$ & $\mathbf{R} \%$ & $\mathbf{S} \%$ & $\mathbf{F \%}$ & $\mathbf{A} \%$ \\
\hline How often do you do your online grocery shopping alone? & 6.8 & 2.3 & 9.1 & 27.3 & 54.5 \\
\hline How often do you buy something on impulse? & 4.5 & 38.6 & 43.2 & 13.6 & 0.0 \\
\hline How often do you try new products or brands? & 2.2 & 24.2 & 53.3 & 20.0 & 0.0 \\
\hline How often do you make a list before starting? & 24.4 & 20.0 & 20.0 & 17.8 & 17.8 \\
\hline How often do you have problems finding items? & 0.0 & 28.9 & 53.3 & 15.6 & 2.2 \\
\hline $\begin{array}{l}\text { How often do you use the "My Favourites" or "Last Order" } \\
\text { teature? }\end{array}$ & 11.4 & 9.1 & 15.9 & 34.1 & 29.5 \\
\hline How often do you use the "Notes" or "Instructions" feature? & 34.1 & 38.6 & 13.6 & 9.1 & 4.5 \\
\hline How often do you scan or browse categories to find an item? & 2.2 & 15.6 & 37.8 & 37.8 & 6.7 \\
\hline How often do you use the Search box to find an item? & 8.9 & 11.1 & 44.4 & 22.2 & 13.3 \\
\hline $\begin{array}{l}\text { How often do you time your online grocery shopping to take } \\
\text { advantage of cheaper delivery charges? }\end{array}$ & 15.6 & 20.0 & 15.6 & 24.4 & 24.4 \\
\hline $\begin{array}{l}\text { How often do you do your online grocery shopping from your } \\
\text { home computer? }\end{array}$ & 0.0 & 11.1 & 20.0 & 20.0 & 48.9 \\
\hline How often do you check out Special offers or items on sale? & 8.9 & 17.8 & 28.9 & 24.4 & 20.0 \\
\hline $\begin{array}{l}\text { ff you need to go to a supermarket, do you go to the same } \\
\text { vendor that provides your online grocery shopping? }\end{array}$ & 4.5 & 15.9 & 38.6 & 18.2 & 22.7 \\
\hline
\end{tabular}

( $\mathrm{SA}=$ Strongly Agree, $\mathrm{A}=\mathrm{Agree}, \mathrm{N}=$ Neutral, $\mathrm{D}=$-Disagree, $\mathrm{SD}=$-Strongly Disagree)

\begin{tabular}{|l|c|c|c|c|c|}
\hline OGS on online grocery shopping & SA\% & $\mathbf{A} \%$ & N\% & D\% & SD\% \\
\hline $\begin{array}{l}\text { I prefer not to be distracted when online grocery shopping, as } \\
\text { I need to concentrate on what I'm doing }\end{array}$ & 4.8 & 26.2 & 42.9 & 26.2 & 0.0 \\
\hline $\begin{array}{l}\text { If I had the time, I would prefer to buy my groceries in person } \\
\text { rather than online }\end{array}$ & 19.0 & 38.1 & 21.4 & 21.4 & 0.0 \\
\hline $\begin{array}{l}\text { I miss being able to pick out my own produce when shopping } \\
\text { online }\end{array}$ & 26.2 & 45.2 & 21.4 & 7.1 & 0.0 \\
\hline $\begin{array}{l}\text { The best thing about buying groceries online is that I spend } \\
\text { less money than I would in a supermarket }\end{array}$ & 7.1 & 35.7 & 38.1 & 14.3 & 4.8 \\
\hline $\begin{array}{l}\text { I'm more likely to buy something new if I see it in a } \\
\text { supermarket or shop than online }\end{array}$ & 28.6 & 45.2 & 14.3 & 11.9 & 0.0 \\
\hline My favourite online grocery site is easy to use & 9.3 & 69.8 & 18.6 & 2.3 & 0.0 \\
\hline $\begin{array}{l}\text { Buying groceries online hasn't affected the types of things I } \\
\text { buy }\end{array}$ & 9.3 & 55.8 & 14.0 & 20.9 & 0.0 \\
\hline $\begin{array}{l}\text { I don't mind talking to people while doing my online grocery } \\
\text { shopping }\end{array}$ & 2.3 & 32.6 & 34.9 & 25.6 & 4.7 \\
\hline $\begin{array}{l}\text { I feel more in control of my grocery shopping when I do it } \\
\text { online }\end{array}$ & 7.1 & 16.7 & 38.1 & 28.6 & 9.5 \\
\hline I don't like being interrupted when grocery shopping online & 4.5 & 47.7 & 38.6 & 9.1 & 0.0 \\
\hline Buying Groceries online saves me money & 13.6 & 27.3 & 29.5 & 22.7 & 6.8 \\
\hline
\end{tabular}

$(\mathrm{SA}=$ Strongly Agree, $\mathrm{A}=\mathrm{Agree}, \mathrm{N}=$ Neutral, $\mathrm{D}=$ Disagree, $\mathrm{SD}=$ Strongly Disagree) 


\begin{tabular}{|l|l|l|l|l|l|}
\hline OGS rating of last site used & $\begin{array}{l}\text { Excellent } \\
\%\end{array}$ & $\begin{array}{l}\text { Good } \\
\%\end{array}$ & $\begin{array}{l}\text { Acceptable } \\
\%\end{array}$ & $\begin{array}{l}\text { Below } \\
\text { Avg.\% }\end{array}$ & $\begin{array}{l}\text { Poor } \\
\%\end{array}$ \\
\hline Ease of Use & 4.8 & 57.1 & 35.7 & 2.4 & 0.0 \\
\hline Quality of Products & 9.5 & 52.4 & 28.6 & 9.5 & 0.0 \\
\hline Product Selection & 9.5 & 61.9 & 28.6 & 0.0 & 0.0 \\
\hline Quality of Service & 21.4 & 52.4 & 23.8 & 2.4 & 0.0 \\
\hline Web Site appearance & 19.0 & 52.4 & 28.6 & 0.0 & 0.0 \\
\hline Price & 16.7 & 61.9 & 21.4 & 0.0 & 0.0 \\
\hline
\end{tabular}

\begin{tabular}{|l|l|l|l|}
\hline OGS behaviour on last site used & Yes \% & No \% & $\begin{array}{l}\text { Don't } \\
\text { Know\% }\end{array}$ \\
\hline Do you store your credit/debit card details on that site? & 50.0 & 45.5 & 4.5 \\
\hline Do you store your login details for that site? & 65.9 & 31.8 & 2.3 \\
\hline $\begin{array}{l}\text { Do you have the web address of the site stored in Bookmarks or } \\
\text { Favourites? }\end{array}$ & 47.7 & 47.7 & 4.5 \\
\hline
\end{tabular}

